\title{
KAJIAN SISTEM PERMINTAAN KOMODITAS SUMBER PROTEIN DI ENAM PROPINSI DI INDONESIA
}

\author{
Nursamsi ${ }^{1}$, Rita Nurmalina ${ }^{2}$, dan Amzul Rifin ${ }^{2}$ \\ 1) Mahasiswa Program Magister Sains Agribisnis, Sekolah Pascasarjana, Institut Pertanian Bogor \\ 2) Departemen Agribisnis, Fakultas Ekonomi dan Manajemen, Institut Pertanian Bogor \\ e-mail : 1)samsihutabarat@gmail.com
}

(Diterima 9 Mei 2019/Disetujui 31 Mei 2019)

\begin{abstract}
The government's commitment to realize national food security through overcome food insecurity and malnutrition as the main program of the Ministry of Agriculture. This study aims to analyze differences in consumption of protein commodities based on two provincial categories and the effect of changes in prices and income on demand of protein commodities. The two provincial catagories are provinces which has protein consumption below Adequacy Rate of Protein (AKP), namely Jambi, Nusa Tenggara Timur, Maluku and provinces which has protein consumption above AKP, namely Jakarta, Jawa Barat, Jawa Timur. This study used the National Socio-Economic Survey (SUSENAS) in March analyzed by using Linear ApproximateAlmost Ideal Demand System (LA/AIDS). The results showed that consumption of fish and meat in provinces above $A K P$ is higher then percapita consumption in provinces below AKP, while the others percapita consumption like poultry, egg, tempeh, and tofu is higher in provinces above AKP. Price and expenditure elasticity is more elastic in provinces above AKP then price and expenditure elasticity in provinces below AKP. Generally, the commodity's own price elasticity is inelastic in both categories of provinces except eggs. The value of egg elasticity is greater than 1 (elastic), either in provinces above AKP or in the provinces below AKP. Based on expenditure elasticity, all commodities are normal goods. Fish, poultry, and eggs are luxury goods in the province above the AKP, while only fish and eggs are luxury goods in the provinces below the AKP.
\end{abstract}

Keywords: AIDS, elasticity, food consumption pattern

\begin{abstract}
ABSTRAK
Komitmen pemerintah untuk mewujudkan ketahanan pangan nasional melalui penanggulangan kerawanan pangan dan gizi buruk adalah program utama Kementerian Pertanian. Penelitian ini bertujuan untuk menganalisis perbedaan konsumsi komoditas protein berdasarkan dua kategori provinsi, dan pengaruh perubahan harga dan pendapatan terhadap permintaan komoditas protein. Kedua kategori provinsi adalah provinsi yang memiliki konsumsi protein di bawah Angka Kecukupan Protein (AKP), yaitu Jambi, Nusa Tenggara Timur, Maluku dan provinsi yang memiliki konsumsi protein di atas AKP, yaitu Jakarta, Jawa Barat, Jawa Timur. Penelitian ini menggunakan Survei Sosial Ekonomi Nasional (SUSENAS) pada bulan Maret yang dianalisis dengan menggunakan Linear Approximate-Almost Ideal Demand System (LA/AIDS). Hasil penelitian menunjukkan bahwa konsumsi perkapita ikan dan daging di provinsi di atas AKP lebih tinggi daripada konsumsi perkapita di provinsi di bawah AKP, sementara konsumsi perkapita yang lain seperti unggas, telur, tempe dan tahu lebih tinggi di provinsi di atas AKP. Elastisitas harga dan pengeluaran lebih elastis di provinsi di atas AKP daripada elastisitas harga dan pengeluaran di provinsi di bawah AKP. Umumnya elastisitas harga komoditas itu sendiri tidak elastis di kedua kategori provinsi kecuali telur. Nilai elastisitas telur lebih besar dari 1 (elastis), baik di provinsi di atas AKP atau di provinsi di bawah AKP. Berdasarkan elastisitas pengeluaran, semua komoditas adalah barang normal. Ikan, unggas dan telur adalah barang mewah di provinsi di atas AKP, sementara hanya ikan dan telur yang merupakan barang mewah di provinsi di bawah AKP.
\end{abstract}

Kata Kunci: AIDS, elastisitas, pola konsumsi makanan 


\section{PENDAHULUAN}

Protein adalah zat makanan berupa asam-asam amino yang berfungsi sebagai pembangun dan pengatur bagi tubu. Protein terdiri atas rantai-rantai asam amino (20 jenis asam amino) yang terikat satu sama lain dalam ikatan peptida. Dari dua puluh macam asam amino, tubuh orang dewasa membutuhkan delapan jenis asam amino esensial yaitu lisin, leusin, isoleusin, valin, triptofan, fenilalanin, metionin, treonin, sedangkan untuk anak-anak yang sedang tumbuh, ditambahkan dua jenis lagi yaitu histidin dan arginin. Adapun contoh asam amino non esensial yaitu prolin, serin, tirosin, sistein, glisin, asam glutamat, alanin, asam aspartat, aspargin, ornitin (Irianto dan Waluyo 2004).

Bahan makanan protein hewani merupakan sumber protein yang baik, dalam jumlah maupun mutu seperti telur susu daging unggas ikan dan kerang. Sumber protein nabati adalah kacang kedelai dan hasil-hasilnya seperti tempe dan tahu serta kacang-kacangan lain. Kacang kedelai merupakan sumber protein nabati yang mempunyai mutu atau nilai biologi tertinggi. Tetapi semua protein kacang-kacangan terbatas dalam asam amino metionin (Adriani dan wirjatmadi 2013).

Konsumsi protein di Indonesia masih rendah dibandingkan dengan negara-negara lain di Asia tenggara, hal ini terlihat dari sumbangan kalori terbesar rata-rata penduduk Indonesia diperoleh dari karbohidrat seperti beras dan pangan lainnya. Berdasarkan rekomendasi Widyakarya Nasional Pangan dan Gizi (WNPG) tahun 2012, jumlah energi yang diperlukan didapat dari 50-60 persen karbohidrat, 25-35 persen lemak, dan 10-15 persen protein. Pangsa konsumsi karbohidrat Indonesia terhadap total energi pada tahun 2013 masih tinggi dibandingkan dengan negara Thailand, Timor Leste, Vietnam, Miyanmar, Brunai, dan Malaysia. Indonesia menempati posisi ke-empat tertinggi konsumsi karbohidrat di Asia Tenggara yaitu sebesar 72,7 persen pada tahun 2013 sedangkan pangsa kalori dari karbohidrat terendah adalah negara Malaysia yaitu sebesar 61,1 persen. Begitu juga halnya dengan sumbangan protein terhadap kalori di Indonesia masih relatif rendah, di mana pangsa protein sebesar 8,95 persen terhadap total energi, masih berada di bawah anjuran WNPG yaitu 10-15 persen. Pangsa protein terhadap kalori menjadi terendah kedua setelah Thailand dari 10 negara Asia Tenggara (FAO 2017).

Berdasarkan Peraturan Menteri Kesehatan No. 75 tahun 2013 dan Rekomendasi Widya Karya Nasional Pangan dan Gizi (WNPG) tahun 2018, pemerintah Indonesia telah menetapkan bahwa kebutuhan energi minimum adalah 2.100 kilokalori per kapita per hari, sedangkan kebutuhan protein minimum atau angka kecukupan protein (AKP) adalah 57 gram per kapita per hari. Berdasarkan data SUSENAS 2016, dari 34 propinsi yang ada di Indonesia saat ini, terdapat 7 propinsi dengan konsumsi protein masih di bawah angka kecukupan protein (AKP) yaitu Kalimantan Barat (56,20 gram), Lampung (55,38 gram), Nusa Tenggara Timur (54,16 gram), Jambi (54,11 gram), Maluku (50,86 gram), Maluku Utara (50,28 gram), dan Papua (43,49 gram). 27 propinsi lainnya sudah mencapai bahkan melebihi standar kecukupan konsumsi protein. Propinsi dengan ratarata konsumsi protein per kapita sehari yang tertinggi adalah DKI Jakarta (68,87 gram) dan DI Yogyakarta (68,16 gram). Setiap propinsi di Indonesia memang memiliki kelimpahan yang berbeda-beda jika dilihat dari ketersediaan komoditas sumber protein tersebut. Misalnya daerah penghasil ikan terbesar terdapat di propinsi Maluku, Sumatera Utara, dan Jawa Timur, sedangkan daerah produsen daging sapi, daging ayam ras, telur terdapat di propinsi jawa timur, Jawa Tengah dan Jawa Barat, sedangkan produsen kedelai terdapat di 
Jawa Timur, Jawa Tengah dan Nusa Tenggara Timur (BPS 2017).

Akibat rendahnya konsumsi protein, di Indonesia telah banyak ditemukan pada anak sekolah dasar antara tahun 1980-1982 di 26 propinsi, didapatkan prevalensi kekurangan protein karena kurang mengonsumsi ikan lebih dari 10 persen dari 966 kecamatan yang diperiksa, dan di beberapa desa 80 persen pendudukyna dengan gondok dan maramus. Kemudian pada tahun 1966 dilakukan survey di tiga propinsi, didapatkan gondok dan maramus 3,1-5 persen di Maluku 33 persen. Berdasarkan data survei pada tahun 1980-1982, diperkirakan 75.000 menderita kretin, 3,5 juta orang dengan gangguan mental, bahkan di beberapa desa 10-15 persen menderita kretin (Adriani dan Wirjatmadi 2013).

Pada tahun 2013 angka kekurangan gizi di wilayah NTT mencapai 50 persen dan pada akhir tahun (Kemenkes RI 2013). Antara tahun 2014-2016, prevalensi gizi buruk di Indonesia mencapai 7,9 persen dengan jumlah gizi buruk 20,3 juta jiwa. Jumlah ini jauh lebih tinggi dibandingkan dengan Malaysia (prevalensi gizi buruk rata-rata hanya 2,6 persen pada tahun 2013-2015), Myanmar, dan Brunai, baik dalam jumlah maupun pertumbuhan konsumsi energi (FAO 2017). Data terbaru pada tahun 2018 jumlah gizi buruk dan gizi kurang pada balita di Indonesia sebesar 17,7 persen (Kemenkes RI 2018).

Komitmen Pemerintah untuk mewujudkan ketahanan pangan nasional, termasuk menanggulangi rawanan pangan dan kekurangan gizi tertuang dalam program utama Kementerian Pertanian. Untuk sub sektor peternakan tertuang dalam program terobosan yaitu program kecukupan pangan hewani. Peningkatan ketahanan pangan nasional pada hakekatnya mempunyai arti strategis bagi pembangunan nasional. Ketersediaan pangan yang cukup, aman, merata, harga terjangkau dan bergizi bagi manusia (Pusdatin Pertanian 2014).
Berdasarkan uraian-uraian di atas perlu dilakukan penelitian bagaimana pola konsumsi komoditas protein di dua kategori propinsi. Yaitu, propinsi yang konsumsi proteinnya sudah di atas AKP dan propinsi yang konsumsi proteinnya masih di bawah AKP. Tujuan penelitian ini adalah menganalisis pola konsumsi dan permintaan pangan sumber protein di propinsi yang termasuk kategori di bawah AKP dan kategori di atas AKP.

\section{METODE}

\section{SUMBER DATA DAN INFORMASI}

Sumber data dalam penelitian ini menggunakan data Survei Sosial Ekonomi Nasional (SUSENAS) Maret tahun 2016. Data yang dipakai adalah variabel konsumsi pengeluaran dalam modul konsumsi. Data yang digunakan adalah data konsumsi kuantitas dan pengeluaran dengan nomor urut untuk kelompok ikan/udang/cumi/kerang, daging, telur dan kacang-kacangan. Selain data kuantitas, nilai pengeluaraan (budget) untuk tiap-tiap komoditas juga diperlukan. Kemudian data lain yang dibutuhkan adalah data jumlah anggota keluarga dan pendapatan total. Informasi terkait dengan kebutuhan penelitian diperoleh dari berbagai sumber yang relevan di antaranya Food Agricultural Organization (FAO) untuk melihat data konsumsi protein di beberapa negara, Kementerian Kelautan dan Perikanan (KKP) Kementan untuk melihat data produksi pangan sumber protein dan Badan Pusat Statistik (BPS) untuk melihat data konsumsi pangan sumber protein.

Terdapat 6 jenis komoditas sumber protein yang dianalisis dalam penelitian ini, yaitu ikan, daging, unggas, telur, tempe dan tahu. Ikan yang dimaksud adalah seluruh variabel konsumsi yang termasuk kelompok ikan dalam kuesioner susenas. Daging terdiri dari daging sapi dan daging babi, unggas terdiri daging ayam ras dan daging ayam kampung, telur terdiri dari telur ayam, telur 
itik dan telur puyuh. Pemilihan keenam komoditas sumber protein ini dikarenakan enam jenis komoditas sumber protein ini termasuk dalam bahan makanan penting di Indonesia dan bahan komoditas sumber protein yang familiar dikonsumsi masyarakat. Selain itu, pemilihan jenis komoditas protein ini karena termasuk menu lauk yang biasa dikonsumsi masyarakat. Nilai harga komoditas sumber protein merupakan harga implisit yang dihasilkan dari proksi total pengeluaran terhadap total konsumsi.

\section{Metode Pengambilan Sampel}

Pengambilan sampel dilakukan secara purposive yaitu propinsi Jambi, Nusa Tenggara Timur (NTT), Maluku, Jawa Timur, DKI Jakarta dan Jawa Barat. Metode pemilihan propinsi berdasarkan Angka Kecukupan Protein (AKP). Propinsi dengan konsumsi di bawah AKP terpilih yaitu Jambi, NTT, dan Maluku. Propinsi Jambi, NTT dan Maluku adalah propinsi yang konsumsi proteinnya paling rendah setelah Papua dan Maluku Utara. Papua dan Maluku Utara tidak dipilih karena dikhawatirkan tidak dapat memenuhi kriteria sampel dalam model karena konsumsinya nol . Alasan lain memilih Maluku adalah produsen perikanan tangkap tertinggi Indonesia dan NTT adalah produsen perikanan budidaya tertinggi setelah Sulawesi Selatan. Kemudian propinsi terpilih dengan konsumsi protein di atas AKP adalah propinsi Jawa Timur, Jawa Barat dan Jakarta dengan pertimbangan bahwa Jawa Timur dan Jawa Barat merupakan sentral produsen peternakan baik sapi, ayam maupun telur. Kemudian Jakarta menarik diteliti karena bukan menjadi produen salah satu komoditas, tetapi memiliki konsumsi protein tertinggi di Indonesia, pun selain Jakarta adalah sebagai pusat distribusi komoditas yang lengkap dan memiliki akses yang mudah terhadap komoditas tersebut karena berada di jantung kota. Waktu penelitian dilakukan tahun 2019.
Metode analisis dalam penelitian ini menggunakan model Approximation Almost Ideal Demand System (LA/AIDS) dan analisis deskriptif membandingkan konsumsi perkapita kedua kategori propinsi. Model Almost Ideal Demand System (AIDS) diperkenalkan oleh Deaton dan Muelbauer (1980) yang sering digunakan dalam pemodelan perilaku konsumsi dengan pendekatan sistem. Model ini digunakan untuk menentukan fungsi permintaan beberapa komoditas dalam satu model. Metode Seemingly Unrelated Regression (SUR) yang dikembangkan oleh Zellner (1963) digunakan untuk mengestimasi persamaan menggunakan alat analisis yang sesuai. SUR digunakan karena model permintaan dengan menggunakan retriksi atau batasan-batasan. Model SUR dapat meningkatkan efiensi dugaan dengan cara mempertimbangkan secara eksplisit bahwa terdapat korelasi sisaan (Zellner 1962). Secara umum model LA-AIDS kategori komoditas adalah fungsi dari harga dan hubungannya terhadap pengeluaran dapat dituliskan sebagai berikut (Widarjono 2016):

$$
\begin{gathered}
w_{i}=\alpha_{i}+\sum_{j=i}^{n} \gamma_{i j} \ln P_{j}+\beta_{i} \ln \left(\frac{x}{\alpha(p)^{*}}\right)+\theta \ln R T+ \\
e_{i}
\end{gathered}
$$

\begin{tabular}{|c|c|}
\hline$i, j$ & $\begin{array}{l}: 1,2,3,4,5,6 \text { (ikan, daging, unggas, } \\
\text { telur, tempe, tahu) }\end{array}$ \\
\hline wi & $\begin{array}{l}\text { :pangsa pengeluaran } \\
\text { komoditas ke-i }\end{array}$ \\
\hline $\operatorname{lnpj}$ & $\begin{array}{l}\text { : Log natural dari harga komoditas } \\
\text { sumber protein }\end{array}$ \\
\hline$x$ & : Total pengeluaran komoditas sumber \\
\hline$P^{*}$ & : indeks harga stone di mana: \\
\hline & $\ln p^{*}=\sum w i \ln p i$ \\
\hline
\end{tabular}

\section{Dimana :}

\section{METODE ANALISIS}


Dalam mengestimasi parameter ai, $\gamma_{\mathrm{ij}}$, dan $\beta \mathrm{i}$ pada peramaan (1), terdapat beberapa batasanbatasan teoritis pada persamaan permintaan seperti di bawah ini:

Adding Up:

$\sum_{i=1}^{n} \alpha_{i}=1, \sum_{i=1}^{n} \gamma_{i j}=0, \sum_{i=1}^{n} \beta_{i}=0$

Homogeneity:

$$
\sum_{i=1}^{n} \gamma_{i j}=\mathbf{O}
$$

Symmetri:

$$
\gamma_{i j}=\gamma_{j i}
$$

Untuk menghitung elastisitas dapat menggunakan elastisitas sendiri dan elastisitas silang uncompensated (Marshallian) dan compensated (Hicksian). Elastisitas Marshalian dan elastisitas Hicksian masing-masing dapat dilihat pada persamaan (3) dan (4) di bawah ini. Di mana $\delta \mathrm{i} j$ adalah delta Kronecker delta yang nilainya " 1 " untuk elastisitas sendiri dan " 0 " untuk elastisits silang. Kemudian elastisitas pengeluaran dihitung seperti pada persamaan (5) (Wadud 2006; Alexandri et al. 2014; Rifin 2013; Zhang et al. 2017).

$$
\begin{aligned}
e_{i j} & =-\delta_{i j}+\frac{\hat{\gamma}_{i j}}{\bar{w}_{i}}-\hat{\beta}_{i}\left(\frac{\bar{w}_{j}}{\bar{w}_{i}}\right) \\
e_{i j}^{*} & =-\delta_{i j}+\frac{\hat{\gamma}_{i j}}{\bar{w}_{i}}+\bar{w}_{j} \\
\eta_{i} & =\mathbf{1}+\frac{{ }^{(5)}}{\overline{\boldsymbol{\beta}}_{i}}
\end{aligned}
$$

Elastisitas pengeluaran sangat penting dalam menentukan atau mengestimasi permintaan di masa mendatang untuk setiap komoditas. Estimasi elastisitas pengeluaran dapat membantu dengan akurat pembuat keputusan untuk meramalkan permintaan dalam jangka pendek, menengah, dan jangka panjang dan membuat keputusan yang tepat pada setiap komoditas dalam model (Chern 2003).

\section{HASIL DAN PEMBAHASAN}

\section{DESKRIPSI PENDAPATAN dan JUMLAH ANGGOTA RUMAH TANGGA}

Pendapatan dapat berbeda disetiap daerah. Pendapatan dan jumlah anggota rumah tangga rumah tangga berhubungan erat tingkat konsumsi rumah tangga. Berikut data jumlah sampel, pendapatan dan jumlah anggota keluarga di kedua kategori provinsi. Tabel 1 menyajikan deskriptif penelitian di kedua kategori propinsi. Pendapatan perkapita per bulan di propinsi di atas AKP lebih tinggi dibandingkan dengan propinsi di bawah AKP. Pendapatan di atas AKP secara rata-rata adalah Rp1.015.624.67,-/kapita/bulan sedangkan propinsi bawah AKP hanya Rp697.759.19,/kapita/bulan. Jumlah anggota rumah tangga di propinsi di atas AKP lebih rendah dibandingkan dengan jumlah angggota rumah tangga di propinsi di bawah AKP.

Table 1. Jumlah Sampel, Pendapatan dan Jumlah Anggota Rumah Tangga Berdasarkan Kategori Propinsi.

\begin{tabular}{|c|c|c|}
\hline Uraian & Propinsi Atas AKP & Propinsi Bawah AKP \\
\hline N (RT) & 57.275 & 21.658 \\
\hline ah ART (orang) & 3,5 & 4,3 \\
\hline patan/kap/bulan & $1.015 .624,67$ & $697.759,19$ \\
\hline
\end{tabular}




\section{KONSUMSI PERKAPITA KOMODITAS PROTEIN BERDASARKAN KATEGORI PROPINSI}

Konsumsi perkapita di propinsi di atas AKP dan di propinsi di bawah AKP dapat dilihat pada Tabel 2. Konsumsi perkapita ikan dan daging lebih tinggi di propinsi di bawah AKP dibandingkan dengan propinsi di atas AKP. Konsumsi ikan secara rata-rata di propinsi di atas AKP hanya 1.110 gr/kapita/bulan. Angka ini lebih rendah 36,67 persen dibandingkan dengan konsumsi ikan di propinsi di atas AKP yang jumlahnya mencapai 1.840 gr/kapita/bulan. Konsumsi daging sebesar 350 gr/kapita/bulan di propinsi di bawah AKP sedangkan di propinsi di atas AKP sebesar 470 gr/kapita/bulan. Konsumsi perkapita daging di atas AKP lebih rendah 25,53 persen dari konsumsi daging di propinsi di bawah AKP. Sementara itu, konsumsi komoditas lain, secara rata-rata jauh lebih tinggi di propinsi di atas AKP daripada di propinsi di bawah AKP.

Konsumsi total protein di propinsi di atas AKP lebih tinggi daripada propinsi di bawah AKP. Konsumsi protein di propinsi di atas AKP sebesar 21,26 gr/kapita/hari sedangkan konsumsi protein di atas AKP hanya 16,12 gr/kapita/hari. Penyumbang terbesar pada konsumsi protein di propinsi di atas AKP adalah komoditas ikan dan tempe, masing-masing 29,9 persen dan 25,8 persen. Sedangkan penyumbang protein terbesar di propinsi di atas AKP adalah ikan hingga 65,38 persen.

Jika dibandingkan angka kecukupan protein WNPG (57 gr/kapita/hari), konsumsi protein ini masih jauh lebih rendah, karena protein yang dihitung masih berasal dari 6 komoditas tersebut di atas. Sedangkan hampir semua makanan yang dikonsumsi mengandung protein meski dalam jumlah yang sedikit seperti beras dan sayur. Rata-rata konsumsi protein Nasional pada tahun 2016 adalah 61,23 gr/kapita/hari. Konsumsi protein ini disumbangkan 33,14 persen dari serealia, 13,36 persen dari ikan, 9,31 persen dari daging, 5,09 persen dari telur dan susu dan 8,43 persen dari kacang-kacangan (BPS 2016)

Konsumsi protein ikan di propinsi di bawah AKP lebih tinggi, tetapi secara keseluruhan, konsumsi protein di propinsi di atas AKP masih jauh lebih tinggi. Hal ini karena di propinsi di atas AKP konsumsi komoditas cenderung merata. Meski konsumsi ikan di propinsi di atas AKP lebih rendah, tetapi konsumsi tempe di propinsi di atas AKP jauh lebih tinggi dibandingkan propinsi di bawah AKP. Smentara itu, kandungan protein tempe jauh lebih besar daripada ikan. Kandungan protein yang tekandung dalam 100 gr ikan rata-rata adalah 17,19 gr sedangkan kandungan protein dalam 100 gr tempe adalah 20.8 gr.

Tabel 2. Sebaran Konsumsi Komoditas Protein Kategori Provinsi

\begin{tabular}{|l|c|c|c|c|}
\hline Komoditas & $\begin{array}{l}\text { Konsumsi } \\
\text { Perkapita } \\
\text { (gr/kap/bln) }\end{array}$ & $\begin{array}{l}\text { Kandungan* } \\
\text { Protein } \\
\text { (gr/kap/hari) }\end{array}$ & $\begin{array}{l}\text { Konsumsi } \\
\text { Perkapita } \\
\text { (gr/kap/bln) }\end{array}$ & $\begin{array}{l}\text { Kandungan* } \\
\text { Protein } \\
\text { (gr/kap/hari) }\end{array}$ \\
\hline Ikan & 1.110 & 6,36 & 1.840 & 10,54 \\
\hline Daging & 60 & 0,35 & 80 & 0,47 \\
\hline Unggas & 510 & 3,09 & 270 & 1,64 \\
\hline Telur & 620 & 2,56 & 250 & 1,03 \\
\hline Tempe & 790 & 5,48 & 210 & 1,46 \\
\hline Tahu & 940 & 3,42 & 270 & 0,98 \\
\hline
\end{tabular}


Kondisi kelimpahan sumberdaya pada propinsi ini akan mempengaruhi perilaku masyarakat dalam mengkonsumsi. Konsumsi unggas dan telur yang tinggi di propinsi di atas AKP tidak terlepas dari ketersediaan dan kemudahan mendapatkanya. Begitu juga halnya konsumsi tempe dan tahu. Produksi kedelai lebih tinggi di propinsi Jatim dan Jabar dibandingkan dengan NTT, Jambi dan Maluku. Produksi kedelai di propinsi Jatim sebesar 344.998 ton, Jawa Barat 98.938 ton, Jambi 6.732 ton, NTT 3.615 ton dan Maluku hanya 707 ton (BPS 2016). Produksi ini akan sangat mempengaruhi pola konsumsi masyarakat pun faktor preferensi tidak dapat diabaikan. Misalnya konsumsi tempe dan tahu lebih tinggi di propinsi di atas AKP karena pada umumnya preferensi masyarakat Pulau Jawa sangat tinggi terhadap tempe dan tahu dibandingkan propinsi di luar Jawa. Hal ini berdasarkan data susenas 2016, konsumsi perkapita tempe dan tahu paling tinggi terdapat di daerah Pulau Jawa dan sejalan dengan penelitian Hanafi et al. (2014). Sama halnya dengan propinsi Maluku, preferensi masyarakat akan lebih tinggi pada komoditas ikan (Trihapsari 2017).

PROPORSI RUMAH TANGGA YANG MENGKONSUMSI KOMODITAS SUMBER PROTEIN DI KEDUA KATEGORI PROVINSI

Berdasarkan Tabel 3 dapat dilihat bahwa proporsi rumah tangga yang mengkonsumsi keenam komoditas jauh lebih tinggi di propinsi di atas AKP dibandingkan dengan propinsi di bawah AKP. Hanya komoditas ikan yang proporsi rumah tangganya sangat tinggi di propinsi di bawah AKP.

Tingginya proporsi rumah tangga yang mengkonsumsi berbagai komoditas di propinsi di atas AKP menyebabkan secara rata-rata konsumsi perkapitanya juga tinggi. Hal ini karena perhitungan nilai perkapita menggunakan total rumah tangga sebagai pembagi, termasuk yang tidak mengkonsumsi. Konsumsi perkapita di propinsi di atas AKP rendah, karena jumlah rumah tangga yang mengkonsumsi juga sangat rendah pada setiap komoditas. Akibatnya, rumah tangga yang konsumsinya nol banyak, sementara perhitungan perkapita menggunakan total rumah tangga secara keseluruhan. Hal ini menggambarkan bahwa, konsumsi komoditas protein tidak merata di propinsi di bawah AKP. Artinya, konsumsi protein hanya dapat di akses oleh sekelompok orang-orang tertentu. Hal ini lah yang menyebabkan berdasarkan data BPS (2016) konsumsi protein di propinsi di bawah AKP masih di bawah angka kecukupan protein yaitu masing-masing, Jambi 54,11 gram/kapita/hari, NTT 54,16 gram/kapita/hari dan Maluku 43,49 gram/kapita/hari sedangkan angka kecukupan protein berdasarkan rekomendasi adalah 57 gram/kapita/hari.

Tabel 3. Proporsi Rumah Tangga yang Mengkonsumsi Komoditas Sumber Protein Berdasarkan Kategori Propinsi

\begin{tabular}{|l|c|c|}
\hline Komoditas & \multicolumn{2}{|c|}{ Proporsi RT yang Mengkonsumi (\%) } \\
Provinsi dibawah AKP \\
\hline Ikan & Provinsi di atas AKP & 89,55 \\
\hline Daging & 83,17 & 8,80 \\
\hline Unggas & 10,34 & 25,53 \\
\hline Telur & 54,69 & 56,99 \\
Tempe & 88,08 & 33,26
\end{tabular}




\section{Tahu \\ 83,74 \\ 67,03 \\ MODEL PERMINTAAN SUMBER PROTEIN}

\section{Keragaan Variabel dalam Model}

Pangsa pengeluaran adalah persentase jumlah uang yang di keluarkan terhadap komoditas dari total pengeluaran keenam komoditas tersebut. Harga dan pengeluaran tiap-tiap komoditas di tiap daerah berbeda, sesuai dengan keadaan demografi, pendapatan dan perilaku masyarakat. Deskripsi statistik dari variabel yang digunakan dalam penelitian ini akan di tampilkan pada Tabel 4. Komoditas dengan pengeluaran terbesar adalah ikan baik di prvinsi di atas AKP maupun propinsi di bawah AKP. pengeluaran ikan masing-masing 30 persen dan 30,1 persen. pengeluaran keenam komoditas di propinsi di bawah AKP
35,08

41,53

berturut-turut untuk ikan adalah 0,31 (31 persen) , daging sebesar 0,28 (28 persen), unggas 23,2 persen dan telur 10,6 persen. Harga rata-rata ikan per kilogram adalah Rp32.825,54, daging Rp90.748,43 per kilogram dan unggas Rp42.767,28 per kilogram.

Harga-harga komoditas di propinsi Jambi, NTT dan Maluku relatif lebih mahal dibandingkan dengan propinsi Jakarta, Jabar dan Jatim. Pada dasarnya daerah Pulau Jawa memang menjadi sentral peternakan baik daging sapi, unggas, dan sentral produksi kedelai. Hal ini akan mempengaruhi ketersediaan dan distribusi komoditas sehingga mempengaruhi harga. Selain ketersediaan dan distribusi, perbedaan harga dapat disebabkan oleh adanya perbedaan kualitas atau grade suatu komoditas, sedangkan dalam penelitian ini perbedaan kualitas diabaikan.

Table 4. Pangsa Pengeluaran Komoditas , Harga, dan Total Pengeluaran Komoditas Sumber Protein Berdasarkan Kategori Propinsi

\begin{tabular}{|c|c|c|}
\hline Variabel & $\begin{array}{c}\text { Propinsi di atas } \\
\text { AKP }\end{array}$ & $\begin{array}{c}\text { Propinsi } \\
\text { diawah AKP }\end{array}$ \\
\hline \multicolumn{3}{|l|}{ Pengeluaran: } \\
\hline Ikan & 0,30 & 0,31 \\
\hline Daging & 0,28 & 0,28 \\
\hline Unggas & 0,18 & 0,23 \\
\hline Telur & 0,12 & 0,10 \\
\hline Tempe & 0,06 & 0,03 \\
\hline Tahu & 0,06 & 0,03 \\
\hline \multicolumn{3}{|l|}{ Harga rata-rata $(\mathrm{Rp} / \mathrm{Kg})$ : } \\
\hline Ikan & $30.782,44$ & $32.825,54$ \\
\hline Daging & $107.671,82$ & $90.748,43$ \\
\hline Unggas & $34.065,43$ & $42.767,28$ \\
\hline Telur & $1.445,02$ & $1.860,39$ \\
\hline Tempe & $10.505,54$ & $11.808,20$ \\
\hline Tahu & $8.956,77$ & $9.183,70$ \\
\hline $\begin{array}{l}\text { Total Pengeluaran Komoditas } \text { Protein } \\
(\mathrm{Rp}) / \mathrm{RT} / \mathrm{Minggu}\end{array}$ & $172.463,76$ & $241.160,68$ \\
\hline Rata-rata jumlah Anggota Keluarga (jiwa) & 4,10 & 5,06 \\
\hline
\end{tabular}


Faktor-Faktor yang Mempengaruhi Permintaan Komoditas Sumber Protein di Propinsi di atas AKP.

Hasil estimasi faktor-faktor yang mempengaruhi permintaan dapat dilihat pada tabel 5 di bawah ini. Variabel independent dalam penelitian ini adalah harga, jumlah anggota keluarga dan pengeluaran/pendapatan. Tabel 5 menunjukkan variabel-variabel yang mempengaruhi permintaan ikan, daging, ayam, telur, tempe dan tahu di propinsi yang konsumsi proteinnya tinggi (Jakarta, Jabar, Jatim).

Penduga koefisien regresi pada sistem permintaan komoditas sumber protein menghasilkan R-square antara 0,0177 sampai
0,1473 dengan tanda koefisien parameter yang beragam yang dapat dilihat di Tabel 5 . Estimasi nilai R-square yang rendah pada persamaan pangsa pengeluaran yang menggunakan data cross section pada beberapa penelitian juga rendah. Seperti penelitian Pusposari (2012) dengan rentang R-square 0,013-0,44 , Basarir (2013) dengan rentang R-square 0,089-0,237, Budiar (2000) dengan R-square 0,13, Huang dan Lin (2000) dengan rentang R-square 0,060,15 . Rendahnya koefisien determinasi (Rsquare) ini disebabkan karena data yang digunakan adalah data cross section karena adanya variasi yang besar antara variabel yang diteliti pada satu periode waktu yang sama (Damodar 2012; Widarjono 2007).

Table 5. Estimasi Model LA-Aids Komoditas Sumber Protein di Propinsi di Atas AKP (Jakarta,

\begin{tabular}{|c|c|c|c|c|c|c|}
\hline \multicolumn{7}{|c|}{ Jabar, Jatim) } \\
\hline Komoditas & Ikan & Daging & Unggas & Telur & Tempe & Tahu \\
\hline Konstanta & 0,2687 & 0,3319 & 0,1169 & 0,1589 & 0,0758 & 0,0478 \\
\hline Harga ikan & $0,0616^{* * *}$ & $-0,0367^{* * *}$ & 0,00224 & $-0,00968^{* * *}$ & $-0,009 * * *$ & $-0,00859 * * *$ \\
\hline $\begin{array}{l}\text { Harga } \\
\text { Daging }\end{array}$ & $-0,0367^{* * *}$ & $0,0389 * * *$ & $-0,05531^{* * *}$ & $0,01472^{* * *}$ & $0,01357^{* * *}$ & $0,02474^{* * *}$ \\
\hline $\begin{array}{l}\text { Harga } \\
\text { Unggas }\end{array}$ & $0,002^{*}$ & $-0,0553^{* * *}$ & $0,0729^{* * *}$ & $-0,01217^{* * *}$ & 0,00074 & $-0,00843^{* * *}$ \\
\hline Harga Telur & $-0,0097^{* * *}$ & $0,01472 * * *$ & $-0,01217^{* * *}$ & 0,0065 & $-0,0003$ & 0,00091 \\
\hline $\begin{array}{l}\text { Harga } \\
\text { Tempe }\end{array}$ & $-0,009^{* * *}$ & $0,01357^{* * *}$ & $0,00074^{* * *}$ & $-0,00033^{* * *}$ & 0,0057 & $-0,01072^{* * *}$ \\
\hline Harga Tahu & $-0,0086^{* * *}$ & $0,02474^{* * *}$ & $-0,00843^{* * *}$ & $0,00091^{* * *}$ & $-0,0107^{* * *}$ & 0,0021 \\
\hline Jumlah ART & 0,00169 & $0,02377^{* * *}$ & 0,00461 & $-0,01986^{* * *}$ & $-0,0034^{*}$ & $-0,00619^{* * *}$ \\
\hline Pengeluaran & $0,04642^{* * *}$ & $-0,09468^{* * *}$ & $0,0063^{*}$ & $0,04787^{* * *}$ & $-0,0054^{*}$ & $-0,00056$ \\
\hline R-Square & 0,0547 & 0,1473 & 0,0468 & 0,1292 & 0,0387 & 0,0177 \\
\hline
\end{tabular}

*Signifikan pada taraf $a=10 \% /{ }^{* *}$ Signifikansi pada taraf $a=5 \% / * * *$ Signifikan pada taraf $\alpha=1 \%$

Variabel harga ikan dan harga daging mempengaruhi seluruh permintaan dalam model baik ikan itu sendiri, daging, daging ayam, telur tempe dan tahu. Variabel harga unggas mempengaruhi seluruh permintaan dalam model kecuali komoditas tempe. Variabel harga telur juga mempengaruhi permintaan ikan, daging, unggas. Secara keseluruhan variabel harga mempengaruhi permintaan komoditas baik harga sendiri maupun harga komoditas lain. Variabel jumlah anggota keluarga hanya mempengaruhi permintaan daging, permintaan telur, tempe dan permintaan tahu. Variabel pengeluaran rumah tangga mempengaruhi seluruh permintaan komoditas kecuali tahu. Hasil ini sesuai penelitian Purba dan Prajogo (2012) dan Ilham (2002) yang menyatakan bahwa selain harga pendapatan juga berpengaruh terhadap konsumsi daging.

Dalam menduga model permintaan, penelitian menggunakan restriksi atau batasanbatasan agar sesuai dengan teori permintaan. Restriksi permintaan tersebut adalah adding up, simetry, dan homogeneity dalam fungsi permintaan. Untuk melihat diberlakukannya 
batasan ini dapat dilihat dengan menjumlahkan parameter-paramter regresi yang di peroleh. Berdasarkan Tabel 6, penjumlahan koefisien parameter dari hasil regresi telah memenuhi syarat-syarat dari adding up, simetry, dan homogeneity yang berarti model yang dihasilkan dalam penelitian ini sudah memenuhi teori permintaan.

Tabel 6. Penjumlahan Parameter Hasil Koefisien Regresi Propinsi di Atas AKP

\begin{tabular}{|l|l|l|l|l|l|l|l|l|} 
Komoditas & Konstanta & Ikan & Daging & Ayam & Telur & Tempe & Tahu & Stone \\
\hline Ikan & 0,2687 & 0,0616 & $-0,0367$ & 0,0022 & $-0,0097$ & $-0,0090$ & $-0,0086$ & 0,0464 \\
\hline Daging & 0,3319 & $-0,0367$ & 0,0389 & $-0,0553$ & 0,0147 & 0,0136 & 0,0247 & 0,0946 \\
\hline Unggas & 0,1169 & 0,0022 & $-0,0553$ & 0,0729 & $-0,0122$ & 0,0007 & $-0,0084$ & 0,0063 \\
\hline Telur & 0,1589 & $-0,0097$ & 0,0147 & $-0,0122$ & 0,0065 & $-0,0003$ & 0,0009 & 0,0479 \\
\hline Tempe & 0,0758 & $-0,0090$ & 0,0136 & 0,0007 & $-0,0003$ & 0,0057 & $-0,0107$ & - \\
\hline Tahu & 0,0478 & $-0,0086$ & 0,0247 & $-0,0084$ & 0,0009 & $-0,0107$ & 0,0021 & - \\
\hline Jumlah & 1 & 0 & 0 & 0 & 0 & 0 & 0 & 0,0054 \\
\hline
\end{tabular}

Faktor-Faktor yang Mempengaruhi Permintaan Komoditas Sumber Protein di Propinsi dengan konsumsi Protein di bawah Angka Kecukupan Protein

Estimasi faktor-faktor yang mempengaruhi permintaan komoditas sumber protein di propinsi yang konsumsi proteinnya di bawah AKP dapat dilihat pada tabel 7 di bawah ini. Tabel 7 menunjukkan variabelvariabel yang mempengaruhi permintaan ikan, daging, ayam, telur, tempe dan tahu di propinsi yang konsumsi proteinnya rendah (Jambi, NTT, Maluku). Penduga koefisien regresi pada sistem permintaan komoditas sumber protein menghasilkan $\mathrm{R}^{2}$ antara 0,0733 sampai 0,2781 dengan tanda koefisien parameter yang beragam yang dapat dilihat di Tabel 7.

Variabel harga ikan mempengaruhi seluruh permintaan dalam model kecuali telur dan daging. Variabel harga daging mempengaruhi permintaan ikan, daging, dan unggas tetapi tidak berpengaruh terhadap permintaan komoditas telur, tempe dan tahu.
Variabel harga unggas mempengaruhi permintaan seluruh komoditas kecuali telur. Variabel tempe mempengaruhi seluruh permintaan dalam model kecuali komoditas tahu. Secara umum harga mempengaruhi permintaan komoditas baik harga sendiri maupun harga komoditas lain. Penelitian yang serupa juga dilakukan oleh Loho at al (2014) dan menemukan bahwa faktor harga daging ayam, harga daging babi, harga daging sapi serta harga ikan, harga tahu dan harga tempe ikut mempengaruhi jumlah permintaan produk peternakan di kabupaten Minahasa Selatan. Variabel jumlah anggota keluarga hanya mempengaruhi permintaan ikan, unggas, dan permintaan telur. Variabel pengeluaran rumah tangga mempengaruhi seluruh permintaan komoditas dalam model kecuali tempe.

Penggunaan retriksi dalam model permintaan di provinsi di bawah AKP dapat dilihat pada penjumlahan parameterparameter regresi yang diperoleh seperti yang disajikan pada tabel 8 .

Table 7. Estimasi Model LA-AIDS Komoditas Sumber Protein di Propinsi di Bawah AKP (Jambi, NTT, Maluku)

\begin{tabular}{|l|l|l|l|l|l|l|}
\hline Komoditas & Ikan & Daging & Unggas & Telur & Tempe & Tahu \\
\hline Konstanta & 0,2512 & 0,3614 & 0,1727 & 0,0628 & 0,1129 & 0,0387 \\
\hline Harga ikan & $0,0784^{*}$ & $-0,0125$ & $-0,0397^{*}$ & $-0,0076$ & $-0,0072^{*}$ & $-0,0111^{*}$ \\
\hline Harga Daging & $-0,0125^{*}$ & $0,0715^{*}$ & $-0,0599^{*}$ & 0,0025 & $-0,0025$ & 0,0011 \\
\hline Harga Unggas & $-0,0397^{*}$ & $-0,0599^{*}$ & $0,11323^{*}$ & $-0,0135$ & $-0,0070^{* *}$ & $0,0069^{* * *}$ \\
\hline Harga Telur & $-0,0076^{*}$ & $0,0025^{*}$ & $-0,0135^{*}$ & 0,0044 & $0,0089^{*}$ & 0,0051 \\
\hline
\end{tabular}




\begin{tabular}{|c|c|c|c|c|c|c|}
\hline Harga Tempe & $-0,0111^{*}$ & $5,7 \mathrm{E}-05^{*}$ & $0,0057^{*}$ & $0,0055^{*}$ & $0,0108^{\star *}$ & $-0,0031$ \\
\hline Harga Tahu & $-0,0076^{*}$ & $-0,0017^{*}$ & $-0,0059^{*}$ & $0,0085^{*}$ & $-0,0030^{* * *}$ & 0,0009 \\
\hline Jumlah ART & $-0,0646^{*}$ & 0,0174 & $0,0606^{*}$ & $-0,0205^{\star *}$ & 0,0015 & 0,0062 \\
\hline Pengeluaran & $0,0865^{*}$ & $-0,091^{*}$ & $-0,0375^{*}$ & $0,0527^{*}$ & $-0,0037$ & $-0,007^{* *}$ \\
\hline R-Square & 0,1539 & 0,1605 & 0,2781 & 0,1447 & 0,1192 & 0,0733 \\
\hline
\end{tabular}

*Signifikan pada taraf $a=1 \% /{ }^{* *}$ Signifikansi pada taraf $a=5 \% / * * *$ Signifikan pada taraf $\alpha=10 \%$

Tabel 8. Penjumlahan Parameter Hasil Koefisien Regresi di Provinsi di Bawah AKP

\begin{tabular}{|c|c|c|c|c|c|c|c|c|}
\hline Komoditas & Konstanta & Ikan & Daging & Ayam & Telur & Tempe & Tahu & Stone \\
\hline Ikan & 0,251253 & 0,07849 & $-0,01253$ & $-0,03971$ & $-0,00757$ & $-0,00724$ & $-0,0111$ & 0,086504 \\
\hline Daging & 0,361425 & $\overline{0}, 01253$ & 0,07153 & $-0,05992$ & 0,00258 & $-0,0025$ & 0,00114 & $-0,09103$ \\
\hline Unggas & 0,172778 & $\begin{array}{l}- \\
0,03971\end{array}$ & $-0,05992$ & 0,11323 & $-0,01345$ & $-0,00706$ & 0,0069 & $-0,0375$ \\
\hline Telur & 0,062828 & $\begin{array}{l}- \\
0,00757\end{array}$ & 0,00258 & $-0,01345$ & 0,00447 & 0,008985 & 0,00519 & 0,052756 \\
\hline Tempe & 0,112968 & $-0,0111$ & 5,7E-05 & 0,00576 & 0,0055 & 0,010882 & $-0,00305$ & $-0,00371$ \\
\hline Tahu & 0,038748 & $\overline{0}, 00756$ & $-0,00171$ & $-0,00592$ & 0,00852 & $-0,00305$ & 0,00097 & $-0,00702$ \\
\hline Jumlah & 1 & 0 & 0 & 0 & 0 & 0 & 0 & 0 \\
\hline
\end{tabular}

Elastisitas Harga Sendiri dan Pendapatan

\section{Elastisistas Harga Sendiri}

Angka elastisitas menggambarkan besarnya perubahan kuantitas yang diminta karena adanya perubahan satu satuan harga. Pada umumnya, elastisitas harga sendiri bertanda negatif yang menandakan bahwa apabila terjadi kenaikan harga pada suatu komoditas maka permintaannya akan menurun. Elastisitas harga sendiri di dapat dilihat Tabel 9.

Table 9. Elastisitas Harga Sendiri Berdasarkan Komoditas dan Kategori Propinsi

\begin{tabular}{|c|c|c|}
\hline \multirow[b]{2}{*}{ Komoditas } & \multicolumn{2}{|c|}{ Elastisitas Harga Sendiri } \\
\hline & $\begin{array}{l}\text { Propinsi di } \\
\text { atas AKP }\end{array}$ & $\begin{array}{l}\text { Propinsi di } \\
\text { bawah AKP }\end{array}$ \\
\hline Ikan & $-0,8400^{*}$ & $-0,8291^{*}$ \\
\hline Daging & $-0,7288^{*}$ & $-0,6514^{*}$ \\
\hline Unggas & $-0,5675^{*}$ & $-0,4585^{*}$ \\
\hline Telur & $-1,0351^{*}$ & $-1,0084^{*}$ \\
\hline Tempe & $-0,9526^{*}$ & $-0,7923^{*}$ \\
\hline Tahu & $-0,9967^{*}$ & $-0,9398^{*}$ \\
\hline
\end{tabular}

*Signifikan pada taraf $\mathrm{a}=1 \% / * *$ Signifikansi pada taraf $\mathrm{a}=5 \% / * * *$ Signifikan pada taraf $a=10 \%$
Telur adalah satu-satunya komoditas yang nilai elastisitasnya lebih besar 1 , baik di propinsi di atas AKP maupun di propinsi di bawah AKP. Angka elastisitas harga sendiri semua komoditas bernilai negatif, artinya kenaikan harga menyebabkan penurunan permintaan. Pada propinsi di bawah AKP, telur adalah komoditas yang paling elastis yaitu -1.0351, artinya persentase perubahan kuantitas yang diminta lebih besar daripada persentase perubahan harga. Telur adalah satusatunya komoditas yang relatife responsif terhadap harga, maka untuk mendorong peningkatan konsumsi, pemerintah harus menjaga stabilisasi harga telur. Harga telur yang terjangkau dapat meningkatkan konsumsi perkapita. Jika harga telur mahal, maka rumahtangga akan mengurangi konsumsinya. Komoditas daging kurang responsif terhadap perubahan harga baik di propinsi di atas AKP maupun propinsi di bawah AKP. Artinya komoditas ini tergolong sulit bagi masyarakat untuk mencari substitusinya. Komoditas yang nilai elasitisitasnya semakin tinggi maka akan cenderung memiliki banyak produk substitusi dan mudah disubstitusikan (Baye dan Jeffrey 2016). 
Untuk meningkatkan konsumsi protein di berbagai daerah dapatlakukan dengan cara yang berbeda sesuai pola konsumsi dan preferensi rumah tangga serta kelimpahan sumberdaya daerah. Kebijakan peningkatan pendapatan dan menjaga stabilitas harga adalah efektif untuk meningkatkan konsumsi komoditas sumber protein rumah tangga yang pada akhirnya dapat meningkatkan konsumsi protein khususnya ikan, telur dan unggas. Hal ini Karena nilai elastisitas harga dan pendapatan komoditas tersebut lebih besar 1 (elastis), artinya rumah tangga akan meningkatkan konsumsi lebih besar dibandingkan dengan peningkatan pendapatan/penurunan harga.

\section{Elastisitas Pendapatan}

Elastisitas pendapatan komoditas sumber protein bertanda positif yang berarti bahwa hubungan pendapatan dan permintaan berbanding lurus. Artinya jika pendapatan meningkat, maka jumlah permintaan komoditas tersebut juga meningkat. Pendapatan dalam analisis elastisitas ini menggunakan pendekatan pengeluaran, yaitu total pengeluaran rumah tangga akan enam komoditas dalam model.

Table 10. Elastisitas Pendapatan Berdasarkan Komoditas dan Kategori Propinsi

\begin{tabular}{|c|c|c|}
\hline \multirow[b]{2}{*}{ Komoditas } & \multicolumn{2}{|c|}{ Elastistas Pendapatan } \\
\hline & $\begin{array}{l}\text { Propinsi di } \\
\text { atas AKP }\end{array}$ & $\begin{array}{c}\text { Propinsi di } \\
\text { bawah AKP }\end{array}$ \\
\hline Ikan & $1,1543^{*}$ & $1,27722^{*}$ \\
\hline Daging & $0,66784^{*}$ & $0,68081^{*}$ \\
\hline Unggas & $1,032455^{*}$ & $0,83885^{*}$ \\
\hline Telur & $1,40476^{*}$ & $1,49726^{*}$ \\
\hline Tempe & $0,90652^{*}$ & $0,888378^{*}$ \\
\hline Tahu & $0,99036^{*}$ & $0,78836^{*}$ \\
\hline $\begin{array}{l}\text { *Signifikan } \\
\text { pada taraf } \\
\alpha=10 \%\end{array}$ & $\begin{array}{l}\text { pada taraf } \\
\mathrm{a}=5 \% /^{* * *} \mathrm{Sig}\end{array}$ & $\begin{array}{l}\% / * * \text { Signifikan } \\
\text { kan pada tar }\end{array}$ \\
\hline
\end{tabular}

Elastisitas pengeluaran dapat dilihat pada Tabel 10. Nilai elastisitas pengeluaran ikan di kedua katagori propinsi lebih besar 1 (elastis), di mana elastisitas pengeluaran di propinsi atas AKP yaitu 1,15 sedangkan di bawah AKP sebesar 1,27. Meski hanya berbeda sedikit, tetapi peningkatan permintaan ikan di propinsi di bawah AKP lebih tinggi jika pengeluaran rumah tangga akan komoditas protein meningkat dibandingkan dengan di propinsi di atas AKP. Elastisitas pengeluaran ikan di propinsi di bawah AKP adalah 1,277 artinya, jika total pengeluaran komoditas protein meningkat 10 persen, maka permintaan ikan akan meningkat sebesar 12,77 persen.

Elastisitas pengeluaran ikan dan telur di propinsi di atas AKP adalah lebih besar 1 . Artinya jika total pengeluaran komoditas protein rumah tangga meningkat, maka rumah tangga akan lebih memilih meningkatkan konsumsi ikan dan telur daripada komoditas yang lain. Kebijakan terhadap peningkatan pendapatan akan efektif untuk meningkatkan konsumsi komoditas, khususnya ikan dan telur. Karena peningkatan pendapatan akan berdampak signifikan pada peningkatan konsumsi komoditas tersebut. Elastisitas pendapatan setiap komoditas berbeda tetapi memiliki tanda yang sama yaitu positif. Keenam komoditas adalah barang normal. Artinya, bila pendapatan yang dialokasikan untuk komoditas sumber protein meningkat maka permintaan akan komoditas tersebut juga meningkat. Penelitian lain juga menemukan hasil yang sama bahwa pendapatan berpengaruh positif terhadap konsumsi pangan seseorang, seperti Paturochman (2005) pada rumahtangga peternak, Faharuddin et al (2013) di Sumatera Selatan pada komoditas susu, daging, buahbuahan, umbi-umbian, padi-padian nonberas, dan ikan, dan Rachmat dan Erwidodo (1990).

Untuk meningkatkan konsumsi komoditas sumber protein di propinsi yang konsumsinya di bawah AKP dapat dilakukan dengan kebijakan harga dan peningkatan pendapatan. Untuk meningkatkan konsumi ikan dapat dilakukan dengan peningkatan pendapatan, sedangkan untuk meningkatkan konsumsi telur dapat dilakukan dengan menurunkan harga telur. Secara umum kebijakan peningkatan pendapatan lebih efektif untuk meningkatkan konsumsi komoditas sumber protein, karena elasitisitas pendapatan masin-masing komoditas lebih tinggi di bandingkan dengan elastisitas harganya sendiri. 


\section{Elastisitas Harga Silang}

Tanda elastisitas harga silang bervariasi baik negatif atau positif tergantung apakah komoditas tersebut saling substitusi atau komplementer. Berdasarkan Tabel 11 dapat diketahui elasitas silang sesama komoditas dalam model permintaan penelitian di propinsi di atas AKP.

Table 11. Elastisitas harga silang komoditas sumber protein di propinsi di Atas AKP (Jakarta, Jabar, Jatim)

\begin{tabular}{|l|l|l|l|l|l|l|}
\hline Komoditas & Ikan & Daging & Unggas & Telur & Tempe & Tahu \\
\hline Ikan & & $-0,0288$ & 0,002682 & $-0,20359^{* * *}$ & $-0,1264^{* * *}$ & $-0,14486^{* * *}$ \\
\hline Daging & $-0,1658^{* * *}$ & & $-0,31656^{* * *}$ & 0,00917 & $0,26078^{* * *}$ & $0,42845^{* * *}$ \\
\hline Unggas & $-0,0203$ & $-0,1344^{* * *}$ & & $-0,17573^{* * *}$ & 0,02959 & $-0,14334^{* * *}$ \\
\hline Telur & $-0,0504^{* * *}$ & $0,09096^{* * *}$ & $-0,07144^{* * *}$ & & 0,00529 & $0,01674^{*}$ \\
\hline Tempe & $-0,0387^{* * *}$ & $0,0669^{* * *}$ & 0,002229 & $-0,02628^{*}$ & & $-0,18387^{*}$ \\
\hline Tahu & $-0,0375^{*}$ & $0,10616^{*}$ & $-0,04873^{*}$ & $-0,02628^{*}$ & $-0,1796^{*}$ & \\
\hline
\end{tabular}

*Signifikan pada taraf $\alpha=10 \% / * *$ Signifikan pada taraf $\alpha=5 \% / * *$ Signifikan pada taraf $\alpha=1 \%$

Semua elastsitas harga silang komoditas tergolong rendah dan lebih kecil satu (inelastis). Dari 30 elastisitas silang, 19 di antara komoditas tersebut kompemen terhadap komoditas lain. Sedangkan sisanya saling substitusi. Ikan komplemen terhadap komoditasi daging, unggas, telur, tempe dan tahu karena tanda elastisitas silangnya negatif. Perubahan permintaan ikan tidak responsif terhadap perubahan harga daging, unggas, telur, tempe dan tahu.

Daging komplemen terhadap unggas, disisi lain, daging juga dapat mensubstitusi telur, tempe, dan tahu. Unggas dan ikan adalah komoditas komplementer. Disisi lain, unggas adalah produk substitusi bagi ikan, tetapi elastisitas silangnya tidak signifikan pada taraf nyata 10 persen. Artinya unggas dapat menggantikan ikan dalam susunan konsumsi rumah tangga, tetapi tidak sebaliknya. Jika ikan tidak tersedia, rumah tangga akan mengantikan konsumsinya dengan unggas. Tetapi jika unggas tidak tersedia, ikan tidak dapat menggantikan ketiadaan unggas, ikan hanya sebagai komoditas pelengkap bagi unggas.

Hal yang sama juga terjadi antara komoditas tempe dan telur. Telur adalah sebagai komoditas komplemen bagi tempe, tetapi telur tidak dapat mensubstitusi tempe. Jika harga telur naik, rumah tangga akan beralih kepada produk substitusinya yaitu tempe. Di provinsi di atas AKP, tempe, selain komplemen terhadap telur, tempe juga mampu mensubstitusi telur. Purba (2014) dengan menggunakan metode yang sama pada data tahun 1996 juga memperoleh hasil bahwa daging sapi berkomplementer dengan daging kerbau, daging babi dan ayam buras. Telur juga memiliki kasus yang sama, dimana telur adalah produk komlementer bagi ikan, unggas dan tempe dan tahu. Sementara tempe dan tahu bersifat komplementer. Untuk elastisitas harga silang di propinsi di bawah AKP dapat dilihat pada Tabel 12.

Berdasarkan Tabel 12, ikan adalah komplemen terhadap komoditasi daging, unggas, telur, tempe dan tahu karena tanda elastisitas silangnya negatif. Perubahan permintaan ikan tidak responsif terhadap perubahan harga daging, unggas, telur, tempe dan tahu. Daging dan ikan adalah produk komplemen, disisi lain daging adalah produk substitusi bagi ikan meskipun nilai elastisitas ini tidak signifikan pada taraf nyata 10 persen. artinya apabila harga ikan naik, rumah tangga akan mengurangi konsumsi ikan dan menggantikannya dengan daging. Tetapi jika harga daging naik, ikan tidak mampu menggantikan daging. Dengan demikian daging adalah komoditas yang tidak dapat di substitusi oleh komoditas apapun, meskipun tahu dapat menggantikan daging, tetapi nilai elastisitas ini tidak signifikan pada taraf nyata 10 persen. 
Table 12. Elastisitas Harga Silang Komoditas Sumber Protein di Propinsi di Bawah AKP (Jambi, NTT, Maluku)

\begin{tabular}{l|l|l|l|l|l|l|} 
Komoditas & \multicolumn{1}{|c|}{ Ikan } & \multicolumn{1}{c}{ Daging } & \multicolumn{1}{c|}{ Unggas } & \multicolumn{1}{|c|}{ Telur } & \multicolumn{1}{|c|}{ Tempe } & \multicolumn{1}{|c|}{ Tahu } \\
\hline Ikan & & 0,05376 & $-0,1255^{* * *}$ & $-0,2225^{* * *}$ & $-0,18324^{* * *}$ & $-0,269^{* * *}$ \\
\hline Daging & $-0,1202^{* * *}$ & & $-0,2126^{* * *}$ & $-0,1177$ & $-0,04328$ & 0,09462 \\
\hline Unggas & $-0,1953^{* * *}$ & $-0,136^{* * *}$ & & $-0,2465^{* * *}$ & $-0,18646^{*}$ & $0,25729^{* * *}$ \\
\hline Telur & $-0,0531^{* * *}$ & 0,04256 & $-0,0431$ & & $0,282088^{* * *}$ & 0,17879 \\
\hline Tempe & $-0,0326^{* * *}$ & 0,00183 & $-0,0251^{*}$ & $0,06822^{* * *}$ & & $-0,0848$ \\
\hline Tahu & $-0,045^{* * *}$ & 0,01456 & $0,0349^{* * *}$ & 0,03247 & $-0,08797$ &
\end{tabular}

*Signifikan pada taraf $\mathrm{a}=10 \% / * *$ Signifikan pada taraf $\mathrm{a}=5 \% / * * *$ Signifikan pada taraf $\mathrm{a}=1 \%$

Pada umumnya sesama komoditas protein saling komplementer, penelitian lain membuktikan bahwa bebrapa produk sumber protein saling kompelmenter, Basarir (2013) di United Arab Emirates menemukan bahwa antara daging kambing dan daging sapi, daging unta dan ayam, daging unta dan daging sapi, daging unta dan ikan adalah produk komplementer sedangkan ayam dan daging unta adalah produk substitusi. Wadud (2006) di Bangladesh menemukan bahwa daging sapi dan ayam, daging sapi dan domba adalah produk substitusi sedangkan daging ayam dan daging domba adalah produk komplemeter.

\section{KESIMPULAN DAN SARAN}

\section{KESIMPULAN}

1. Konsumsi perkapita ikan dan daging di propinsi di bawah AKP lebih tinggi daripada di propinsi di bawah AKP. Sedangkan konsumsi perkapita unggas, telur, tempe dan tahu lebih tinggi di propinsi di atas AKP dibandingkan dengan propinsi di bawah AKP.

2. Secara umum faktor harga berpengaruh signifikan terhadap permintaan komoditas, baik harga sendiri maupun harga komoditas lain di kedua kategori propinsi. Di propinsi di atas AKP, jumlah anggota keluarga signifikan mempengaruhi permintaan daging, telur dan tahu. Sedangkan di propinsi bawah AKP, jumlah anggota keluarga signifikan mempengaruhi permintaan ikan, ayam dan telur.

3. Umumnya elastisitas harga sendiri komoditas adalah inelastis di kedua kategori propinsi kecuali telur. Nilai elastisitas telur lebih besar 1 (elastis), baik di propinsi di atas AKP maupun di propinsi di bawah AKP. Berdasarkan elastisitas pendapatan/pengeluaran, seluruh komoditas adalah barang normal. Ikan, unggas dan telur adalah barang mewah di propinsi di atas AKP, sedangkan di propinsi bawah AKP hanya ikan dan telur yang menjadi barang mewah.

\section{SARAN}

Hasil analisis data memberikan rekomendasi bahwa untuk meningkatan konsumsi protein dapat di tempuh dengan peningkatan pendapatan masyarakat, menjamin adanya ketersediaan dan distribusi komoditas dengan harga yang lebih murah, karena harga berpengaruh secara signifikan terhadap permintaan komoditas sumber protein. Melihat secara keseluruhan nilai elastisitas harga dan pendapatan cenderung tidak elastis, maka dalam rangka meningkatkan konsumsi protein juga perlu sosialisasi untuk meningkatkan kesadaran dan animo masyarakat tentang pentingnya konsumsi protein yang seimbang dan beragam. Rumah tangga harus lebih meningkatkan lagi konsumsi komoditas protein sesuai preferensi masyarakat dan kelimpahan sumberdayanya. Karena jika dilihat dari proporsi rumah tangga yang mengkonsumsi masing-masing komoditas, dan jenis komoditas yang rumah tangga di propinsi di bawah AKP masih kurang keterlibatannya dalam mengkonsumsi keenam komoditas selain ikan.

Penelitian ini belum dapat menggambarkan perbedaan kualitas 
komoditas dalam model, serta terbatas pada konsumsi komoditas mentah. Peneliti selanjutnya diharapkan dapat memasukkan perbedaan kualitas agar hasil yang di peroleh lebih baik serta memasukkan komoditas sumber protein yang berupa makanan jadi dalam model, guna melihat keterkaitan dan perilaku masyarakat dalam mengkonsumsi komoditas protein secara utuh.

\section{DAFTAR PUSTAKA}

Adriani, M., Wirjatmadi B, 2013, Pengantar Gizi, Jakarta (ID): Kencana.

Alexandri C, Pauna B, Luca L. 2014. An estimation of food demand system in Romania - implications for population's food security. ProcediaE+F. 22(2015):577-586.doi: 10.1016/S2212-5671(15)00263-4.

Badan Penelitian Pengembangan dan Kesehatan, 2013, Riset Kesehatan Dasar 2013, Kementerian Kesehatan.

Basarir, A., 2013, An almost ideal demand system analysis of meat demand in UAE, Bulg Agric J Sci. 19 (1):32-39.

Baye, MR., Jeffrey TP., 2016, Ekonomi Manajerial dan Strategi Bisnis, Jakarta (ID): Salemba Empat

[BPS] Badan Pusat Statistik, 2016, Data Produksi Kedelai Berdasarkan Provinsi Tahun 2015.

[BPS] Badan Pusat Statistik, 2016, Konsumsi Kalori dan Protein Penduduk Indonesia dan Propinsi, Jakarta (ID): BPS.

[BPS] Badan Pusat Statistik, 2017. Data Produksi Ikan dan Daging Berdasarkan Provinsi Tahun 2016.

Budiar, S., 2000, Analisis Permintaan dan Konsumsi Sumber Protein Hewani Rumah Tangga di Pulau Jawa [skripsi], Bogor (ID). Institut Pertanian Bogor.
Budiwinarto, K., 2013, Penerapan model almost Ideal Demand System (AIDS) pada pola konsumsi pangan rumahtangga nelayan di Kecamatan Tambak kabupaten Banyumas, Fakultas Ekonomi Universitas Surakarta.

Chern, W. S., 2003, Analysis of the food consumption of Japanese households: Food and Agriculture Organization of the United Nations.

Damodar N., Gujarati, Dawn CP, 2009, Basic Econometric 5th Edition. New York: McGraw -Hill

Deaton A, Muellbauer J. 1980. An Almost Ideal Demand System. The American Economic Review. 70(3):312-326.

[FAO] Food Agricultural Association, 2017.

Huang KS, Lin BH, 2000, Estimation of Food Demand and Nutrient Elasticities from Household Survey Data, USDA Economic Research Service, Technical Bulletin 1887.

Ilham, N., Hastuti, S., Karyasa IK, 2002, Pendugaan parameter dan elastisitas penawaran dan permintaan beberapa jenis Gizi dan Pola Hidup Sehat, Bandung (ID): Yrama Widya.

[KKP] Kementerian Kelautan dan Perikanan, 2018, Kelautan dan Perikanan dalam angka.

Irianto, K., Waluyo, K., 2004, permintaan pangan hewani Indonesia dengan generalized method of moments pada model quadratic almost ideal demand system, Universitas Pakuan Bogor.

[Kemenkes] Kementerian Kesehatan RI, 2013. Hasil Utama Riset Kesehatan Dasar 2013.

Dasar 2018.

2018. Riset Kesehatan

Loho, R., Rorimpandey, B., Massie, M.T., Santa, N., 2014, Analisis permintaan produk 
peternakan di desa Tawaang kecamatan Tenga kabupaten Minahasa Selatan, Jurnal Zootek. 34(2):57-64.

Paturochman, M., 2005, Hubungan antara tingkat pendapatan keluarga peternak dengan tingkat konsumsi, Sosiohumaniora, 7(3):264 - 272.

Purba, R.P., 2014, Analisis perubahan pola konsumsi daging di Indonesia [tesis], Bogor (ID): Institut Pertanian Bogor.

Purba, H.J., Hadi, P.U., 2012, Dinamika dan kebijakan pemasaran produk ternak sapi potong di Indonesia Timur, PSEK, 10(4): 361-373.

[Pusdatin] Pusat Data dan Informasi Pertanian, 2014, Buletin Konsumsi Pangan TW I 2014, Sekretariat Jenderal Pertanian.

Pusposari, F., 2012, Analisis Pola Konsumsi Pangan Masyarakat di Provinsi Maluku [tesis]. Jakarta (ID). Universitas Indonesia.

Rachmat, M., Erwidodo, 1990, Pendugaan permintaan pangan utama di Indonesia: penerapan model almost ideal demand system (AIDS), Pusat Penelitian Sosial Ekonomi Pertanian.

Rifin, A., 2013, Analysis Of Indonesia's Market Position In Palm Oil Market in China And India, Journal of Food Products Marketing, 19(4):299-310, DOI: 10.1080/10454446.2013.726950.

Setjen Pertanian, 2017, Outlook Daging Sapi Komoditas Subsector Peternakan, Pusat Data Dan Sistem Informasi Pertanian Sekretariat JenderalKementerian Pertanian, ISSN 19071507.

Ayam Ras Komoditas Subsector
Peternakan, Pusat Data Dan Sistem
Informasi Pertanian Sekretariat
Jenderal-Kementerian Pertanian, ISSN
1907-1507.

Trihapsari AL., 2017, Analisis Perkembangan Pola Konsumsi Pangan Menurut Wilayah dan Tingkat Pendapatan di Provinsi Maluku Tahun 2009-2015 [skripsi]. Bogor (ID). Institut Pertanian Bogor.

Wadud, M.A., 2006, An analysis of meat demand in Bangladesh using the almost ideal demand system. The Empirical Economics Letters. 5(1).

Widarjono, A., 2007, Ekonometrika Teori dan Aplikasi Untuk Ekonomi dan Bisnis, Yogyakarta: Penerbit Ekonosia.

Zhang H, Wang J, Martin W. 2017. Factors affecting households' meat purchase and future meat consumption changes in China: a demand system approach. JEF.20(2018):1-9.doi: 10.1016/j.jef.2017.12.004.

Zellner, A., 1963, Estimators for seemingly unrelated regression equations: Some exact finite sample results. Journal of the American Statistical Association, pp. 977-992.

- 1992, An Efficient Method of Estimating Seemingly Unrelated Regressions and Tests for Aggregation Bias. Journal of the American Statistical Association, vol 57 no 298 pp 348-368. 